\title{
Abrasion Resistance of Composites Polymerized by Light-Emitting Diodes (LED) and Halogen Light-Curing Units
}

\author{
Janisse MARTINELLI ${ }^{1}$ \\ Fernanda de Carvalho Panzeri PIRES-DE-SOUZA ${ }^{1}$ \\ Luciana Assirati CASEMIRO² \\ Camila TIRAPELLI ${ }^{1}$ \\ Heitor PANZERI ${ }^{1}$ \\ ${ }^{1}$ Department of Dental Materials and Prosthodontics, Faculty of Dentistry of Ribeirão Preto, \\ University of São Paulo, Ribeirão Preto, SP, Brazil \\ ${ }^{2}$ School of Dentistry, University of Franca (UNIFRAN), Franca, SP, Brazil
}

\begin{abstract}
This study compared the abrasion resistance of direct composite resins cured by light-emitting diodes (LED) and halogen light-curing units. Twenty specimens (12 mm in diameter; $1.0 \mathrm{~mm}$ thick) of each composite resin [TPH (Dentsply); Definite (Degussa); Charisma (Heraus Kulzer)] were prepared using a polytetrafluoroethylene matrix. Ten specimens per material were cured with the LED source and 10 with the halogen lamp for $40 \mathrm{~s}$. The resin discs were polished, submitted to initial surface roughness reading $(R a$ initial - $\mu \mathrm{m})$ in a roughness tester and stored in water at $37^{\circ} \mathrm{C}$ for 15 days. The specimens were weighed (M1) and submitted to simulated toothbrushing using slurry of water and dentifrice with high abrasiveness. After 100 minutes in the toothbrushing simulator, the specimens were cleaned, submitted to a new surface roughness reading ( $R a$ final - $\mu \mathrm{m})$ and reweighed (M2). Mass loss was determined as the difference between M1 and M2. Data were recorded and analyzed statistically by one-way ANOVA and Tukey Test at 5\% significance level. The composite resin with greater size of inorganic fillers (TPH) showed the lowest mass loss and surface roughness means, indicating a higher resistance to toothbrush abrasion $(\mathrm{p}<0.05)$. Definite cured with LED presented the least resistance to toothbrush abrasion, showing the highest means of surface roughness and mass loss $(\mathrm{p}<0.05)$. The LED source did not show the same effectiveness as the halogen lamp for polymerizing this specific composite resin. When the composite resins were cured a halogen LCU, no statistically significant difference was observed among the materials ( $\mathrm{p}>0.05)$. It may be concluded that the type of light-curing unit and the resin composition seemed to interfere with the materials' resistance to abrasion.
\end{abstract}

Key Words: abrasion resistance, composite resin, light-curing, LED, halogen lamp.

\section{INTRODUCTION}

Esthetics has gained more importance day after day, which has made esthetic materials like composite resins the restorative materials of choice in many clinical situations. There are several types of composite resins and most of them are cured by traditional halogen lightcuring units (LCUs). These devices, however, promote a high temperature rise that is felt by the operator during activation, and therefore require the use of filters to protect the dental tissue. The heat produced by the halogen lamps may cause pulpal necrosis because it has been shown that only a few additional degrees lead to irreversible pulpal alterations (1). In addition, conventional halogen LCUs present a decrease in light intensity over time. This limits their lifetime and demand lamp replacement, which is costly (1-5).

In view of these shortcomings, newer curing systems, such as light-emitting diodes (LED) have been introduced due to the need for developing LCUs that did not have the inconveniences as those of the halogen lamps. According to the manufacturers, some of the

Correspondence: Profa. Dra. Fernanda de Carvalho Panzeri Pires-de-Souza, Faculdade de Odontologia de Ribeirão Preto, USP, Av do Café, S/N, 14040-904 Ribeirão Preto, SP, Brasil. Phone: +55-16-36024081. Fax: +55-16-39173384. e-mail: ferpanzeri@forp.usp.br 
advantages of LED LCUs include lower heat production, constant light production (even over time), narrow wavelength $(470 \mathrm{~nm})$ and integral absorption of its light spectrum by camphorquinone, the photoinitiator most commonly found in resin-based materials $(4,5)$. However, there are resins and direct composites that do not use camphorquinone as a the initiator of curing.

Several studies $(2,3,6)$ have tested the hypothesis that LED LCUs can equal halogen LCUs in terms of depth of cure of dental composites. According to Mills et al. (2), LED LCUs may be used in dental practice because their performance does not significantly reduce over time as do conventional halogen LCUs. On the other hand, LED curing lights have been shown to have significant potential but lower curing effectiveness than higher powered halogen curing lights (7). Other authors (8) have found that LED LCUs and those with a combination of LED and halogen LCUs require a greater exposition time than most halogen LCUs to obtain an appropriate cure, regardless of the type of resin used. Moreover, a recent study (9) has raised concern about the degree of polymerization by halogen or LED LCUs in different areas of compomer specimens (the top surface, which receives light directly, and the bottom surface, which is more distant from the light source). No statistically significant difference was observed between the curing systems in terms of hardness on the top surface, whereas their results on the bottom surface differed statistically in most cases. Another investigation (10) evaluated the effect of the increase of energy density on Knoop hardness of Z250 and Esthet-X composite resins; the authors found that higher Knoop hardness was obtained when the energy density was increased.

Regarding microleakage, LED light has been shown to have similar effectiveness as that of halogen light (11). A recent study (12) found statistical similarity between LED and halogen lights for surface hardness and depth of cure for specimens up to 2-mm thick. Increasing in thickness resulted in inefficient curing by LED LCUs. This study assessed the influence of lightemitting diodes (LED) and halogen light-curing units on the abrasion resistance of esthetic restorative materials.

\section{MATERIAL AND METHODS}

Specimen Preparation. The following materials were used: a hybrid composite resin (TPH; Dentsply,
Petrópolis, RJ, Brazil), a microhybrid composite resin (Charisma; Heraus Kulzer, Hanau, Germany) and a modified composite resin (Definite; Degussa, Hanau, Germany).

The specimens were prepared using a polytetrafluoroethylene matrix with a central circular cavity $(12 \mathrm{~mm}$ in diameter and $1 \mathrm{~mm}$ deep). The composite resin was inserted into the matrix in a single increment using a Thompson hand instrument (Duflex, Rio de Janeiro, RJ, Brazil). A glass plate was gently pressed over the resin to provide a smooth and flat surface. The composite resin was light-cured through the glass plate using a blue LED LCU (Ultraled; Dabi Atlante SA, Ribeirão Preto, SP, Brazil; $120 \mathrm{~mW} / \mathrm{cm}^{2}$ output) and a halogen LCU (Ultralux; Dabi Atlante SA). Twenty specimens per material were obtained, 10 of each being cured by one of the light sources (Ultraled or Ultralux). Curing time was $40 \mathrm{~s}$ ( $20 \mathrm{~s}$ over the glass plate and $20 \mathrm{~s}$ without the glass plate).

The cured specimens were removed from the matrix using the screw-on embolus on its bottom side. The specimen surface that was in contact with the bottom of the matrix was polished with Sof-Lex disks (3M/ESPE, St. Paul, MN, USA), following a decreasing sequence of abrasiveness.

Surface Roughness Test. Surface roughness of the polished specimens was evaluated in a roughness tester (Prazis RUG-03 digital Roughness Meter, ARO, Argentine). Three measurements were accomplished and the average ( $R a$ initial $-\mu \mathrm{m})$ was obtained with $\lambda \mathrm{c}$ (meter cut-off) set for a distance of $4.8 \mathrm{~mm}$. After roughness reading, the specimens were stored in water at $37^{\circ} \mathrm{C} \pm 1{ }^{\circ} \mathrm{C}$ for hydration during 15 days.

Mass Loss Test. After storage, the specimens were dried with absorbent paper to remove excess water but were kept moist. Then, 1 min later, specimens were weighed in a digital analytic balance accurate to 0.0001 g (Model AB204-S, Mettler-Toledo, Greifensee, Switzerland) to obtain the initial mass (M1). After weighing, the specimens were prepared for the wear abrasion test in a Pepsodent-type toothbrushing abrasion simulator (developed at the Precision Workshop at Faculty of Dentistry of Ribeirão Preto/USP, Brazil). This equipment is composed of a solid and heavy base containing six stainless steel recipients that allow simultaneous toothbrushing of six specimens. For the purposes of the study, each composite resin disc was individually fixed on the center of a Plexglass plate by 
adding a drop of acrylic resin monomer (JET, Clássico, São Paulo, SP, Brazil) on its surface and pressing the specimen against the plate for $10 \mathrm{~s}$. The Plexglass plates were constructed with the dimensions required by the toothbrushing equipment (i.e., $50 \mathrm{~mm}$ long, $20 \mathrm{~mm}$ wide and $3 \mathrm{~mm}$ thick).

Six Plexglass plates containing the composite resin disks were taken to the toothbrushing abrasion simulator and fixed to the stainless steel recipients with low fusion compound. For each sample, the head of a Kolynos soft-bristle toothbrush (Colgate-Palmolive Indústria e Comércio Ltda., São Paulo, SP, Brazil) was used. The toothbrush head was separated from the handle and attached to the arm of the machine allowing the toothbrush bristles to be positioned parallel to the specimen surface.

As abrasive agent, a suspension of a dentifrice with high abrasiveness (Sorriso Branqueador Brite; Colgate-Palmolive Indústria e Comércio Ltda.) and deionized water were prepared in a 1:1 rate at room temperature. The specimens were fully covered with 15 $\mathrm{mL}$ of the dentifrice/water suspension. Both slurry and toothbrush heads were replaced for every new sample.

Before the wear test began, the equipment was calibrated to level the toothbrush bristles parallel to the sample surface, thus providing uniform toothbrushing. Afterwards, toothbrushing was accomplished at a frequency of $356 \mathrm{rpm}$ with horizontal movements of the toothbrush heads under a $200 \mathrm{~g}$ load and a travel course of $3.8 \mathrm{~cm}$. Each group of specimens was subjected to a 100-min simulated toothbrushing that performed a total of 35,600 brushings per test.

After toothbrushing, the specimens were washed, cleaned to remove dentifrice residues and the composite

Table 1. Means $(\mu \mathrm{m})$ and standard deviations of the difference between initial and final surface roughness for composite resins polymerized with two types of light-curing units.

\begin{tabular}{lcc}
\hline Material & \multicolumn{1}{c}{ LED } & Halogen \\
\cline { 2 - 3 } TPH & $0.448 \pm 0.337 \mathrm{aA}$ & $0.232 \pm 0.146 \mathrm{aA}$ \\
Charisma & $6.265 \pm 3.785 \mathrm{aB}$ & $3.040 \pm 0.787 \mathrm{aA}$ \\
Definite & $9.892 \pm 0.856 \mathrm{aC}$ & $2.518 \pm 1.486 \mathrm{bA}$ \\
\hline
\end{tabular}

Means followed by the same lowercase letters in lines and uppercase letters in columns indicate no statistical difference at 95\% confidence level (Tukey's test; $\mathrm{p}<0.05$ ). resin discs were removed from the Plexiglass plates with the aid of a scalpel blade. Next, the final mass (M2) of the hydrated specimens was determined. Mass loss was obtained by calculating the difference between initial and final mass.

The specimens were then submitted to a postabrasion surface roughness reading ( $R a$ final $-\mu \mathrm{m})$. However, at this time, the equipment's needle was positioned in such a way that the tracing direction was perpendicular to course of the toothbrushing movement, with the aim of detecting the undulations caused by the abrasion procedure. The roughness tester detected the surface irregularities transverse to matrix direction that correspond to peaks, valleys and waves produced by the toothbrushing.

Data were analyzed statistically by one-way ANOVA and Tukey test at 5\% significance level.

\section{RESULTS}

Surface roughness and mass loss means are shown in Tables 1 and 2.

Regarding surface roughness, the light-curing units yielded statistically significant results $(\mathrm{p}>0.05)$, except for Definite group in which the specimens polymerized with LED showed statistically significant higher roughness means $(p<0.05)$. No statistically significant difference was observed among the composite resins light-cured with the halogen lamp ( $>0.05$ ). On the other hand, when the LED unit was the curing system, the composite resins differed statistically $(p<0.05)$ to each other, Definite showing the highest roughness means followed by Charisma and TPH (Table 1).

Table 2. Mass loss means (mg) and standard deviations for composite resins polymerized with two types of light-curing units.

\begin{tabular}{lcr}
\hline Material & \multicolumn{1}{c}{ LED } & \multicolumn{1}{c}{ Halogen } \\
\cline { 2 - 3 } TPH & $0.0100 \pm 0.003 \mathrm{aA}$ & $0.006 \pm 0.002 \mathrm{aA}$ \\
Charisma & $0.0290 \pm 0.008 \mathrm{aB}$ & $0.0182 \pm 0.008 \mathrm{aA}$ \\
Definite & $0.0300 \pm 0.008 \mathrm{aB}$ & $0.014 \pm 0.007 \mathrm{bA}$ \\
\hline
\end{tabular}

Means followed by the same lowercase letters in lines and uppercase letters in columns indicate no statistical difference at 95\% confidence level (Tukey's test; $\mathrm{p}<0.05$ ). 
Regarding mass loss, the light-curing units yielded statistically significant results $(p>0.05)$, except for Definite group in which the specimens polymerized with LED showed statistically significant higher mass loss $(p<0.05)$. When the resins were light-cured by the halogen source, no statistically significant difference was observed among them $(p>0.05)$. However, when the LED unit was used, Definite and Charisma had the highest mass losses and both materials differed statistically from TPH $(p<0.05)$ (Table 2$)$.

\section{DISCUSSION}

The hypothesis investigated in this study was based on the fact that LEDs are light-curing units with advantages such as allowing smaller composite polymerization shrinkage and lack of material heating during polymerization.

Resistance to abrasion is an important property of dental materials in terms of the quality of the restoration. Materials that are highly resistant to abrasion yield more durable restorations, with a lesser marginal leakage and higher color stability.

Depending on the type, particle size, characteristics and composition of the inorganic filler, composite resins may present different behaviors in terms of mass loss (abrasion) and surface roughness after toothbrushing, with no direct relation between them. In this study, the difference between the initial and final mass was calculated to determine composite wear (abrasion). The findings of a recent study (13) have shown that Surefil composite resin (Dentsply) presented low wearing after simulated toothbrushing and a high surface roughness alteration, owing to the presence of large-sized inorganic particles; Solitaire and Charisma (Kulzer) composite resins presented a very good smoothness after brushing, but also had high abrasion. There are also resins that have low levels of wearing and excellent surface smoothness after toothbrushing (Z100, $\mathrm{Z} 250$ and $\mathrm{P} 60 ; 3 \mathrm{M})$. Hence, this study compared composite resins polymerized by two types of curing systems (LED and halogen lamp), before and after toothbrushing, and found that the curing method influenced the material's resistance to abrasion.

Charisma's great surface roughness as well as its great mass loss may be justified. A material submitted to abrasion may have its roughness increased or reduced, depending on the proportion organic matrix/inorganic fillers and particle size in its composition $(14,15)$. Therefore, materials with a greater amount of organic matrix, comparatively to the amount of filler, tend to have greater mass loss upon abrasion. This was observed with Charisma, which is a microhybrid resin with medium-sized particles $(0.85 \mu \mathrm{m})$, i.e, the great mass loss led to a great matrix wear and exposure of inorganic filler, making material surface rougher.

Definite's great mass loss may be explained by its composition. This material has phenylpropanedione (PPD) as photoinitiator, which needs a wavelength of nearly $410 \mathrm{~nm}$ to be activated. Nevertheless, the light produced by the LED source has an intensity of 450-490 $\mathrm{nm}$ (with its maximum peak at $470 \mathrm{~nm}$ ). This range is within the absorption spectrum of camphorquinone $(468 \mathrm{~nm})$, the photoinitiator found in most resin-based materials, but not in Definite $(1,3)$. If the wavelength emitted by the LCU is not capable of effectively activating the photoinitiator, the curing reaction will be compromised because the monomers will not be totally converted into polymers. Failure of a LCU to effectively promote full mass curing will probably result in the formation of an apparently solid restoration body but with physical and mechanical properties that diverge from those of a highquality material (15-17).

Based on the findings of the present study, it may be concluded that the composite resin with greater size of inorganic fillers (TPH) was the one that showed the lowest mass loss and surface roughness means, indicating a higher resistance to toothbrush abrasion. Comparing the curing systems, Definite was the only material that had significantly different results as polymerized with either of the light-curing units, i.e., the LED source did not show the same effectiveness as the halogen lamp for polymerizing this specific composite resin. The type of light-curing unit and the resin composition seemed to interfere with the materials' resistance to abrasion.

\section{RESUMO}

O trabalho comparou a perda de massa e a rugosidade superficial de materiais restauradores diretos polimerizados por luz halógena e por diodo emissor de luz (LED). A partir de uma matriz de politetrafluoretileno, foram confeccionados 20 corpos-de-prova (12 mm de diâmetro; 1,0 mm de espessura) para cada material restaurador [TPH (Dentsply); Definite (Degussa); Charisma (Heraus Kulzer)], sendo 10 espécimes polimerizados por LED e 10 polimerizados por luz halógena durante $40 \mathrm{~s}$. Os corpos-deprova foram polidos, levados ao rugosímetro para análise da rugosidade superficial ( $R a$ inicial - $\mu \mathrm{m}$ ) e armazenados em água a 
$37^{\circ} \mathrm{C}$ por 15 dias. Os corpos-de-prova foram pesados (M1) e submetidos a escovação simulada com suspensão preparada com dentifrício de alta abrasividade. Após 100 minutos no simulador de escovação, os espécimes foram limpos e tiveram o peso (M2) e rugosidade superficial $(R a$ final $-\mu \mathrm{m})$ aferidos novamente. A perda de massa foi calculada pela diferença entre M1 e M2. Os dados foram registrados e analisados por meio de ANOVA a um critério e teste de Tukey para diferenciação das médias com nível de significância de 5\%. Os resultados demonstraram que a resina Definite foi o material que apresentou menor resistência à abrasão quando polimerizada com luz LED, apresentando maiores valores de rugosidade superficial e perda de massa $(p<0.05)$. Quando utilizada a lâmpada halógena, os valores não mostraram diferença estatisticamente significante entre si $(p>0.05)$. O LED não mostrou a mesma eficiência que a lâmpada halógena para polimerização desta resina especificamente. Pode-se concluir que a unidade de luz fotopolimerizadora e a composição das resinas compostas interferiram na resistência à abrasão dos materiais restauradores testados.

\section{REFERENCES}

1. Kurachi C, Tuboy AM, Magalhaes DV, Bagnato VS. Hardness evaluation of a dental composite polymerized with experimental LED-based devices. Dent Mater 2001;17:309315.

2. Mills RW, Jandt KD, Asworth SH. Dental composite depth of cure with halogen and blues light emitting diode technology. Br Dent J 1999;186:388-391.

3. Jandt KD, Mills RW, Blackwell GB, Ashworth SH. Depth of cure and compressive strength of dental composites cured with blue light emitting diodes (LEDs). Dent Mater 2000;16:41-47.

4. Stahl F, Ashworth SH, Jandt KD, Mills RW. Light-emitting diode (LED) polymerisation of dental composites: flexural properties and polymerization potential. Biomaterials 2000;21:1379-1385.

5. Bennett AW, Watts DC. Performance of two blue lightemitting-diode dental light curing units with distance and irradiation-time. Dent Mater 2004;20:72-79.

6. Mills RW, Uhl A, Blackwell GB, Jandt KD. High power light emitting diode (LED) arrays versus halogen light polymerization of oral biomaterials: Barcol hardness, compressive strength and radiometric properties. Biomaterials 2002;23:2955-2963.

7. Burgess JO, Walker, RS, Porche CJ, Rappold, AJ. Composite hardness cured with four LED and one quartz-tungsten halogen curing lights. Compend Contin Educ Dent 2002; 23:889-892, 894, 896; quiz 908.

8. Leonard DL, Charlton DG, Roberts HW, Cohen ME. Polymerization efficiency of LED curing lights. J Esthet Restor Dent. 2002;14:286-295.

9. Okte Z, Villalta P, Garcia-Godoy F, Garcia-Godoy F Jr, Murray P. Effect of curing time and light curing systems on the surface hardness of compomers. Oper Dent 2005;30:540545.

10. Correr AB, Sinhoreti MAC, Correr Sobrinho L, Tango RN, Schneider LFJ, Consani S. Effect of the increase of energy density on knoop hardness of dental composites light-cured by conventional QTH, LED and xenon plasma arc. Braz Dent J 2005;16:218-224.

11. Micali B, Basting RT. Effectiveness of composite resin polymerization using light-emitting diodes (LEDs) or halogenbased light-curing units. Braz Oral Res 2004;18:266-270.

12. Tsai PC, Meyers IA, Walsh LJ. Depth of cure and surface microhardness of composite resin cured with blue LED curing lights. Dent Mater 2004;20:364-369.

13. Garcia FC, Wang L, D'Alpino PH, Souza JB, Araujo PA, Mondelli RF. Evaluation of the roughness and mass loss of flowable composites after simulated toothbrushing abrasion. Braz Oral Res 2004;18:156-161.

14. Braem M, Lambrechts P, Vanherle G, Davidson CL. Stiffness increase during the setting of dental composite resins. J Dent Res 1987;66:1713-1716.

15. Martins F, Delbem AC, Santos LR, Soares HL, Martins Ed Ede O. Microhardness of resins as a function of color and halogen light. Braz Oral Res 2002;16:246-250.

16. Kawaguchi M, Fukushima T, Miyazaki T. The relationship between cure depht and transmission coefficient of visiblelight-activated resin composites. J Dent Res 1994;73:516521.

17. Darvell BW. Resin restorative materials In: Materials Science for Dentistry. Darvell BW (Editor). 6th ed. Hong Kong: Hong Kong University; 2000. p.111-138.

Accepted October 13, 2005 